\title{
A Study on Global Investors' Criteria for Investment in the Local Currency Bond Markets Using AHP Methods: The Case of the Republic of Korea
}

\author{
Jae Young Jang ${ }^{1,2, *}$ and Min Jae Park ${ }^{1}$ (i) \\ 1 Seoul Business School, aSSIST, 46 Ewhayeodae 2-gil, Seodaemun-gu, Seoul 03767, Korea; \\ mjpark2@assist.ac.kr \\ 2 BSL Business School Lausanne, Rte. de la Maladière 21, P.O. Box, 1022 Chavannes (VD), Switzerland \\ * Correspondence: jyljang@yahoo.co.kr
}

Received: 2 September 2019; Accepted: 23 September 2019; Published: 1 October 2019

\begin{abstract}
Global investors' investment in local currency bonds, especially Korea Treasury Bonds, has increased significantly since the mid-2000s, and their influence on bonds and financial markets has grown consistently. In this paper, we investigate global investor's priority of decision factors in investing in Korea Treasury Bonds by distributing a pairwise comparative survey to experts and analyzing the results using the analytical hierarchy process technique. For analysis, we created model frames with experts in the field of investment based on literature analysis, selected survey participants by considering their institution of their employment, work experience and region, and obtained responses. We find that investors with short-term investment propensities are more sensitive to international and domestic factors and less to risk factors, and more heavily influenced by U.S. dollar funding conditions. On the other hand, investors with long-term investment tendencies are found to be more sensitive to international and risk factors as opposed to domestic factors, and influenced by: global policy rate decisions and fiscal soundness, sovereign credit rating, possible global economic recession, and geographical risks. Our findings not only contribute to enhancing investors' understanding of the Korean bond market by discussing consensus among investors, but also provide policy implications for Korean government policymakers who need stable and sustained funding.
\end{abstract}

Keywords: local currency bond markets; Korea Treasury Bonds (KTBs); global investor's consensus; investment decision; financing risk management; analytical hierarchy process (AHP)

\section{Introduction}

This study aims to identify the decision factors that affect investments in local currency (LCY) bonds, and more specifically, the factors that global portfolio investors consider in investing in Korea Treasury bonds (KTBs), and provide implications for the Korean government to proactively manage financing risks and raise funds in a sustainable manner.

Since the Asian financial crisis of the late 1990s, global investors' investments in emerging economies have increased dramatically and their influence in the financial markets has expanded (Lavigne et al. 2014). This contributed greatly to reducing the currency imbalance between emerging economies' assets and debt and increasing the maturity of national debt, which eventually provided stable financing to the market and increased the efficiency of capital allocation (Peiris 2010; Kim and Jung 2015). However, it has been found that global investors' investment in LCY bonds during the global financial crisis could have a negative impact on the domestic economy (Christensen et al. 2019). This was because global investments in LCY bonds at that time were 
excessively concentrated in short-term profits, making them highly vulnerable to market shocks. In fact, as market volatility increased during the global financial crisis, the outflow of global investment funds in a short period of time unnerved most emerging countries' financial markets and economy (Asian Development Bank 2018).

Therefore, the purpose of this study is to analyzes the factors that investors consider in deciding whether to invest in KTBs in order to identify the paths and patterns of global investors and to recommend how to proactively prepare for sudden capital outflow.

Development of the Republic of Korea (ROK)'s LCY bond market is remarkable. The size of LCY the bond market in the ROK has grown tremendously over the past two decades, with its outstanding balance rising from KRW 85.8 trillion as of the end of 1998 to KRW 1724 trillion as of the end of 2018. The proportion of Korean LCY bonds held by global investors has increased from 0.6 percent (KRW 4.6 trillion) in 2006 to 6.6 percent (KRW 113.8 trillion) in 2018, and the number of countries investing in the Korean LCY bond market has also increased from 19 in 2006 to 47 in 2018 (Ministry of Economy and Finance 2019).

As shown in Table 1, global investors' investments in Korean LCY bonds mostly consist of KTBs, and Monetary Stabilization Bonds (MSBs) issued by central bank of Korea (BOK). As of the end of 2018, KTBs and MSBs accounted for $75.8 \%$ and $23.0 \%$ of global investors' total LCY bond investments in Korea, respectively.

Table 1. The status of global investors' LCY bond investments.

\begin{tabular}{ccccccccccc}
\hline & $\mathbf{2 0 0 9}$ & $\mathbf{2 0 1 0}$ & $\mathbf{2 0 1 1}$ & $\mathbf{2 0 1 2}$ & $\mathbf{2 0 1 3}$ & $\mathbf{2 0 1 4}$ & $\mathbf{2 0 1 5}$ & $\mathbf{2 0 1 6}$ & $\mathbf{2 0 1 7}$ & $\mathbf{2 0 1 8}$ \\
\hline Total * $^{*} 57.5$ & 74.2 & 83.0 & 91.0 & 94.7 & 100.4 & 101.4 & 89.3 & 98.5 & 113.8 \\
$\left(\%{ }^{* *}\right)$ & 5.6 & 6.6 & 6.9 & 7.0 & 6.8 & 6.9 & 6.5 & 5.6 & 5.9 & 6.6 \\
KTBs * $^{*}$ & 28.7 & 47.7 & 60.9 & 56.9 & 58.3 & 65.9 & 67.9 & 72.5 & 77.8 & 86.3 \\
$\left(\%\right.$ ** $^{*}$ & 9.8 & 15.4 & 17.9 & 15.7 & 14.5 & 15.0 & 13.8 & 14.0 & 14.2 & 15.2 \\
MSBs * $^{*}$ & 28.1 & 25.4 & 20 & 31.6 & 34.4 & 33.2 & 32.7 & 15.5 & 19.5 & 26.2 \\
$\left(\%{ }^{* *}\right)$ & 18.3 & 15.5 & 11.9 & 19.4 & 20.8 & 18.7 & 17.9 & 9.2 & 11.4 & 1.3 \\
\hline
\end{tabular}

Notes: * Amount held by global investors (unit: in trillion KRW); ${ }^{* *}$ The share of global investors' bonds holding against total listed LCY bonds in Korea. Source: Ministry of Economy and Finance (MoEF).

ROK's LCY bond market is one of the most attractive markets for global investors. The size of the LCY bond market in the ROK is the world's fourth-largest, with LCY bond liquidity at the world's highest level and the country's sovereign rating at a stable level. In addition, various derivative markets for risk hedging are well developed (Asian Development Bank 2018). However, recent economic and political situations are not favorable for the Korean bond market. Concerns over trade disputes between the U.S. and China are growing, economic indicators in the ROK have worsened recently, and financial market volatility has been growing (Asian Development Bank 2019). For emerging economies that are relatively vulnerable to market volatility, it is important to be proactive against these potential risks.

With regards to methodology, we use analytic hierarchy process (AHP) techniques to prioritize the factors that influence global investors' decisions to invest in KTBs. The AHP method has been very limited so far in financial market research, and this is the first time that this methodology is being used in research on the Korean financial market. To achieve the purpose of this study, a literature review based on previous studies and in-depth interviews with experts were conducted, and AHP analysis was conducted using the pairwise comparative survey of experts with extensive investment experience in various institutions and regions.

So far, most previous studies have provided fragmentary analysis of whether certain variables influence global investors' decision to invest in KTBs by analyzing arbitrary financial and economic variables. As the result, the implications provided by these studies were limited, as they do not fully reflect the various investment decision factors of global investors, such as political risk, regulatory changes, market uncertainty, property rights, and so on. This study aims to provide policy implications 
by considering a large number of variables that can affect global investors' decision-making and by surveying experts with extensive experience in investing in the Korean bond market and conducting empirical analyses based on them. This is significant in that it provides strategic insights for preemptive response to future financial crises.

The remainder of the paper is organized as follows: Section 2 provides a review of the literature. Section 3 states the framework of the methodology, and Section 4 describes the hierarchical structure. Section 5 reports the results of analysis and Section 6 concludes with implications.

\section{Literature Review}

To date, research on global investors' investment in Korean LCY bonds has been conducted to a limited extent. Previous studies identified arbitrage trading opportunities in the Korean bond market as one of the major reason for global investors' investment, and analyzed the impact of changes in financial market prices, such as credit default swap, interest rate and foreign exchange rate, on global investors' investment in Korean LCY bonds. However, these analyses tend to overlook factors that could seriously affect global investors' investment, such as changes in the market environment, political instability, policy uncertainty, and changes in rules and regulations.

While investments in commercial banks and private funds, which are sensitive to short-term profits, have declined in recent years, bond investments by global pension funds and central banks with long-term investment tendencies have increased significantly. Therefore, the main challenge of this study is to identify the more diverse investment goals of global investors and analyze the determinants of LCY bond investments. In this section, we provide a detailed review of the existing literature, as it is important to review each of the factors investigated in previous literature to enhance the objectivity of this study and to perform comprehensive analysis.

Exchange rate (FX) fluctuations have a direct impact on international trade as well as on cross-border financial investments. Theoretical analysis of the effects of FX volatility on international investment began in the late 1980s. Several studies of advanced and emerging countries have demonstrated that increased FX volatility has a negative impact on financial investment between countries, and that the stock, bond, commodity and FX markets are closely related to each other (Gyntelberg et al. 2014; Mun 2007; Burger and Warnock 2007). On the other hand, Kim (2012) analyzed that FX rate fluctuations do not have a significant impact on bond investments, but have a negative impact on the stock market.

Previous studies have shown that central banks' rate policies, especially the Fed's policy rate decision, have a significant impact on the bond and stock markets. Several studies examined the impact of policy rate decisions on market liquidity (Christiano and Eichenbaum 1992; Leeper and Gordon 1992). Additionally, some have studied the transmission path of central bank's interest rate policy (Bernanke and Blinder 1992; Gordon and Leeper 1994; Strongin 1995; Christiano et al. 1996). Kontonikas and Zekaite (2018) analyzed that the stock market showed greater gains when eased policy rates coincided with a recession, and when there is a bearish market with tightened credit conditions. The Fed's policy rate's impact on the Korean financial markets were also analyzed. Park and Kim (2013) concluded that the U.S. Fed's policy rate decision after the global financial crisis had a significant impact on the price of KTBs and market synchronization. Jang and Atukeren (2019) recently argued that rising bond yields may have a short-term negative impact to investors but a positive impact in the mid- to long-term.

Estrella and Mishkin (1995) argued that the yield curve slope is a useful predictor of recession and found that short-term and long-term interest rates reversed during the U.S. recession. Bordo (2008) argued that the yield curve helps predict actual economic growth and that using both the level and the slope of the curve improves the predictability.

A cross-currency basis swap spread is a liquidity premium for other currencies added to one sector of the swap, which has a significant impact on cross-border investments. In the mid-2000s, widening of the KRW basis swap spread was a major motivation for global investors to sharply increase their investment in KTBs. Many studies explained the spread of cross-currency basis swap spread through the 
theory of interest rate parity (Popper 1993; Takezawa 1995; Du et al. 2018). Miron and Swannell (1991) argued that capital market imbalances could temporarily push the underlying spread out of range of reasonable prices, but quickly recover from market participants' arbitrage trading. However, Shapiro (2006) argued that excessive government intervention and regulation in the capital market could weaken the market's price-recovery capability and maintain an abnormal spread.

The TED spread refers to the difference in interest rates between the three-month Treasury bill and the three-month London Interbank Offered Rate (LIBOR). Because the U.S. Treasury Bill is a risk-free asset and US LIBOR includes bank credit risk that occurs when the International Bank borrows money, expansion of the TED spread is regarded as an increase in the risk of default on interbank loans. When global liquidity dried up during the 2007-2009 financial crisis, the TED spread reached 450 basis points. Kawaller (1997) argued that reduction of the TED spread raises asset prices, including stocks and bonds, and that the TED spread provides information to predict future interest rates.

Several studies have shown that there is a reverse correlation between the bond market and the stock market (Baele et al. 2010; Connolly et al. 2005; Bekaert et al. 2009). Campbell et al. (2013) argued that bonds could be a hedging instrument for equity that holds risk. Antonakakis et al. (2013) argued that market uncertainty is more important than fundamentals in causing volatility in stock prices, volatility in bond yields, and covariance. Lee (2002) reported that stocks and bonds were highly correlated before the Asian financial crisis, and afterwards, there was a greater correlation between the foreign exchange market and stock market volatility.

Credit default swap (CDS) is a financial derivative or contract that allows the counterparty to exchange or offset credit risk and is used as a measure of credit risk in the financial markets. Since JP Morgan started trading it in the late 90s, CDS has been studied for price models by several researchers including Hull et al. (2004) and Houweling and Vorst (2005). CDS has become a very popular way to manage credit risk. The Office of the Comptroller of the Currency (OCC) stated in a June 2018 report that the total credit derivatives market size was US\$ 4.2 trillion, of which the CDS market accounted for the largest portion with US\$3.68 trillion. Duffie (1998) argued that CDS premium and corporate bond spreads should theoretically be the same. Kim et al. (2013) said that there is a long-term correlation between CDS and bond spreads in emerging countries, while Hong (2011) argued that there is a strong correlation between CDS and FX rates in emerging countries.

Volatility in the financial market leads to less stability and efficiency in the market, which leads to worse performances by financial institutions and weakening of the effects of government's monetary policies. It also increases market uncertainty, which leads to higher market risk premium and results in a contraction of economic activity. The Chicago Board Options Exchange (CBOE) Volatility Index (VIX) is a common indicator of stock market expectations of variability implied by the S\&P 500 index option. It is calculated and distributed in real time by the CBOE and is commonly referred to as the fear index or the fear gauge. There are several previous studies on market volatility. Hamilton (2003) pointed out that the volatile relationship between the oil and stock markets is highly correlated because volatility in the oil market reflects uncertainty in economic growth. Zhang and Wei (2010) argued that there is a significant causal link between volatilities in oil and gold.

There are studies that examined the impact of a country's macroeconomic indicators and fiscal soundness on investment. Bjornland and Lietemo (2009) confirmed that there is a very high correlation between the U.S.'s monetary policy and the return on investments in S\&P 500 . Mahmood and Dinniah (2009) looked at the relationship between the CPI, industrial production index, FX, interest rate and stock price in the six Asian countries (Malaysia, Korea, Thailand, Hong Kong, Japan and Australia) and found that macroeconomic factors and stock prices had a long-term correlation. Ang and Piazzesi (2003); Diebolda et al. (2006); Wright and Zhou (2009) argued that increased industrial output and inflation had a positive impact on bond risk premiums.

So far, there are different views on the impact that a country's fiscal deficit, government debt and economic growth have on investment. The prevailing view is that high fiscal deficit and government debt could cause high inflation, raise long-term interest rates and lead to more tax collection, which 
would negatively affect economic growth. In extreme cases, it can lead to a financial crisis in the country. On the other hand, if a nation's fiscal expansion and inflow of foreign capital are used for productive investments, it can have a positive impact on economic growth in resource-poor and undeveloped countries. However, excessive capital inflows from abroad can lead to macroeconomic imbalances, such as an oversupply of total demand, overheating of the economy, inflation, rising real foreign exchange rates and worsening current account conditions. From a global investor's perspective, the level of foreign exchange reserves in a country can be an indicator of safety of an investment country. Emerging economies, which suffered from the financial crisis in the late 1990s, have significantly increased their foreign reserves since then, creating a safety net for the financial market. Aizenman and Lee (2007) argued that countries with large foreign reserves and stable foreign exchange rates could reduce potential losses to their economies in times of crisis.

It is difficult to quantify and analyze the effectiveness of certain political events. However, Nordhaus (1975) and MacRae (1977) tried to analyze the relationship between economic performance and political events. Since then, Herbst and Slinkman (1984) found a correlation between the presidential race and the primary cycle. Le and Zak (2006) argued that economic risks, policy changes and most importantly, political instability are closely correlated with capital outflows. Bilson et al. (2002) found that emerging countries with low political risk had approximately 11 percent higher returns than countries with higher political risk.

The Korean Peninsula has one of the highest geopolitical uncertainties in the world, and the potential danger of conflict still exists. In addition, geopolitical tensions between the two Koreas are a risk that investors should always pay attention to, but there is a lack of in-depth research in this topic. Ahn et al. (2010) and Kim (2011) analyzed stock price changes of inter-Korean news, and found that global investors were not sensitive to changes in inter-Korean relations. Jang and Atukeren (2019) also found that geopolitical risks on the Korean Peninsula affected global investors' investment in government bonds, but only in the short-term.

Uncertainty in the government's economic policy is another important factor that affects economic and investment decisions. Pastor and Veronesi (2012) argued that uncertainty in the U.S.'s economic policies is a risk factor that could affect stock volatility and future corporate profits. Bloom (2014); Basu and Bundick (2017) pointed out that economic policy uncertainties lead to a delay in corporate decision-making, decrease in corporate investments, and household spending, and rise in savings, which negatively affects the domestic economy. Jang and Atukeren (2019), however, claimed that economic policy uncertainties does not have a statistically significant impact on global investors' investment in KTBs.

With regards to methodology, research on financial markets using the AHP method has been rare to date. Bahmani et al. (1987) used the AHP model to analyze the priority of factors that affect global investors' investment decisions, taking into account factors such as the characteristics of the investor, nature of the investment, and alternatives to the investment. Characteristics of the investor consisted of variables such as the investor's wealth, experience, age, and utility functions. Analysis of the nature of the investment included analysis of data related to liquidity, taxation, minimum requirements, transaction costs and rate of return. Cheung and Liao (2009) used the AHP analysis method to evaluate and select a stock portfolio. They classified the criteria for stock selection into six categories: image, indicators, earnings, performance, risk, and account, and concluded that the investment's performance had the most weight amongst them. In a multi-dimensional decision-making study on corporate bond investments, Liao and Cheung (2012) analyzed investments using data on five categories: performance indicators, interest risk, credit risk, inflation risk, and liquidity.

\section{Methodology}

The AHP is a multiple criteria decision-making technique based on a hierarchical structure that uses eigen values and eigen vector methods to determine the relative weights of criteria and alternatives. The AHP method is a measurement that relies heavily on expert judgment to derive priority scales 
(Saaty et al. 1980), helps organize problems hierarchically and make decisions based on multiple criteria through quantitative and qualitative analysis (Steiguer et al. 2003).

\subsection{Decision Framework}

\subsubsection{Application of the AHP Method}

In this paper, the analysis is performed with a five-step framework as shown in Figure 1. The following are the steps of its application:

Step 1: Identify the determinants of the investors' investment decisions through literature research and point out limitations and problems of existing studies. This was completed in the literature review section of this paper.

Step 2: By analyzing the results of the literature research and conducting expert interviews and brainstorming sessions, construct a hierarchical structure of decision-making factors.

Step 3: Design the questionnaire for pairwise comparison, distribute it to experts, and gather results. Step 4: Check for consistency.

Step 5: Evaluate it and prioritize the factors.

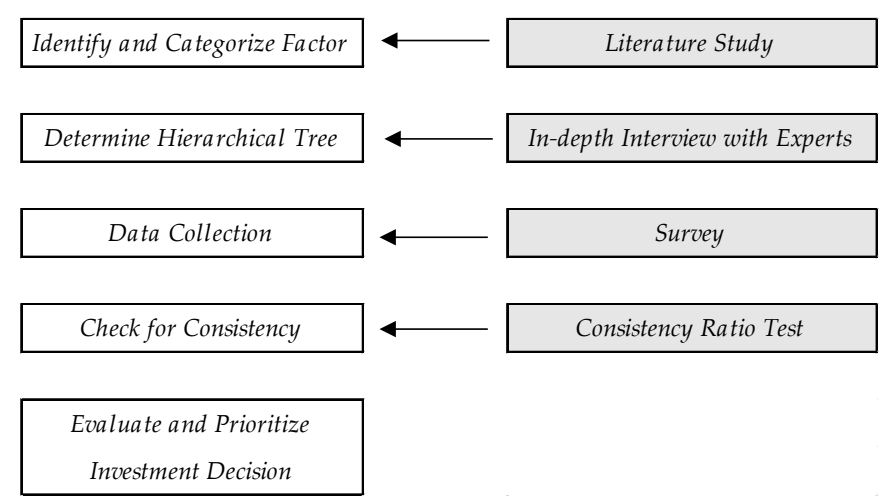

Figure 1. Flow diagram of the decision factor framework.

\subsubsection{Derivation of Components}

The most important feature of the AHP analysis method is to derive the relative importance of the components through layer-by-layer component separation. This is done by separating the various evaluation elements that make up the problem into more detailed elements (Triantaphyllou 2000).

With componentization completed, the AHP can now be used to construct a multi-dimensional decision-making framework that can identify factors that affect global investors' investments in government bonds. In the literature review section, we looked at the factors that affect global investors' decisions on cross-border investments, including KTBs, and extracted them into 8 factors and 42 sub-factors. This is summarized in Table 2.

Table 2. Factors affecting cross-border investment investigated in existing literature.

\begin{tabular}{ll}
\hline \multicolumn{1}{c}{ Factor } & \multicolumn{1}{c}{ Sub-Factor } \\
\hline Interest Rate & $\begin{array}{l}\text { Policy Rate, Short term Interest Rate (KRW Call and US\$ LIBOR), KTB (or MSB) } \\
\text { Yields, U.S. Treasury Yields, Turnover Ratio, Bid-Ask Spread, EMBI (Emerging } \\
\text { Market Bond Index) }\end{array}$ \\
\hline Spread and Curve & KTB (or MSB) TED CCIRS Spread, Basis Swap, US\$ TED, Yield Curve Scope \\
\hline FX & FX Spot (and Dollar Index), FX Swap, FX Volatility \\
\hline Stock & KOSPI, Dow, S\&P 200, MSCI G7, MSCI World, VIX \\
\hline CDS & ROKCDS, CDX, PIIGS CDS \\
\hline Oil & Crude Oil \\
\hline
\end{tabular}


Table 2. Cont.

\begin{tabular}{ll}
\hline \multicolumn{1}{c}{ Factor } & \multicolumn{1}{c}{ Sub-Factor } \\
\hline Macroeconomic Indicators & CPI, M2, GDP, Current Account, CLI \\
\hline \multirow{3}{*}{ Others } & Credit Rating, Sovereign Debt, Fiscal Deficit, Foreign Reserve, Property Rights, \\
& Settlement System, Market Transparency, Political Events, Geopolitical Risk, \\
& Policy Uncertainty, Regulation, Taxation \\
\hline
\end{tabular}

\section{Composition of Hierarchical Structure}

To determine the weight of each item, the assessment criteria was set up through expert interviews and brainstorming, and the survey was conducted.

\subsection{Developing the Assessment Criteria}

We conducted in-depth interviews and brainstorming sessions with experts on two occasions, 17 June 2019 and 26 June 2019. A total of five experts participated in the in-depth interviews and brainstorming sessions, each with more than 30 years of experience in making an investment decision or policy decisions with regards to KTBs. At time of writing, they work for the central bank of Korea, an investment bank, an insurance company, and trust and asset management companies.

In the first session, we presented the panel with the individual factors obtaining from existing literature along with the purpose of this study. Through a three-hour brainstorming session, the panels decided to adopt the framework presented by Jang and Atukeren (2019), which has three factors: domestic, international, and risk. Further, the appropriate sub-criteria for each factor was also discussed. The four sub-criteria for domestic factors were: KTB yield, KTB TED, ROK CDS, and KRW FX. For international factors, three sub-criteria were discussed: US Treasury yield curve slope, US\$ TED, and policy rate. Finally, there were seven sub-criteria for the risk category: policy uncertainty, geopolitical risk, fiscal soundness, credit rating, regulation, operational risk, and compliance risk.

In the second session, the panel had a two-hour open discussion to finalize the assessment criteria. The panel decided to add market liquidity (bid-offer spread) to the domestic factors, fear gauge (VIX) and global stock price indices to the international factors and tax and property rights to the risk factors. The panel also decided to eliminate compliance risk and operational risk as sub-criteria, as they were deemed to be insignificant and a duplicate of other factors being considered.

As a result, the three-stage working framework for AHP analysis was determined as shown in Figure 2. It consists of domestic, international and risk criteria, with five sub-criteria for each criterion.

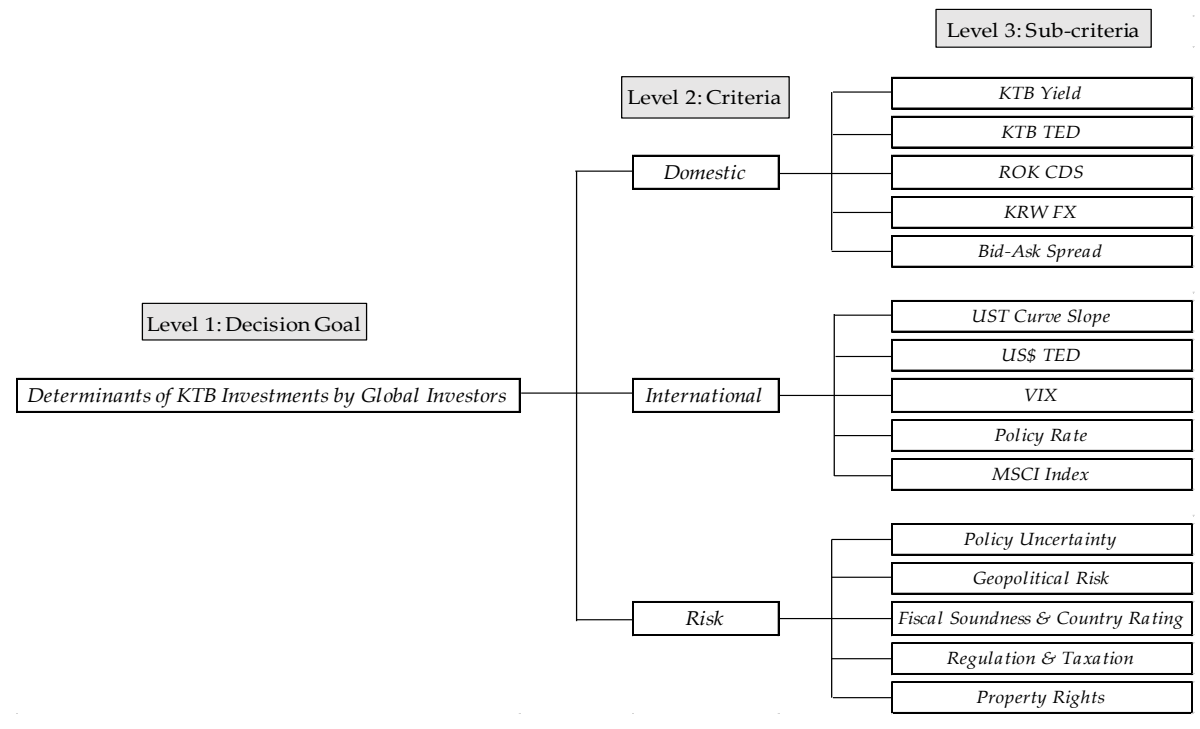

Figure 2. Hierarchical structure and composition of evaluation criteria. 
The description of each criteria is shown in Table 3.

Table 3. Description by factor.

\begin{tabular}{|c|c|c|}
\hline Criteria & Sub-Criteria & Description \\
\hline \multirow{5}{*}{$\begin{array}{l}\text { Domestic } \\
\text { Factors }\end{array}$} & KTBs Yield & $\begin{array}{l}\text { The KTB Yield is the benchmark return on the Korean LCY } \\
\text { bond market. }\end{array}$ \\
\hline & $\begin{array}{l}\text { KTB TED } \\
\text { CCIRS Spread }\end{array}$ & $\begin{array}{l}\text { The KTB TED spread is the interest rate difference between the } \\
\text { KTB and the KRW/US } \$ \text { cross currency interest rate swap, } \\
\text { which is the KTB risk-free arbitrage spread, excluding } \\
\text { sovereign default risks. }\end{array}$ \\
\hline & ROK CDS & $\begin{array}{l}\text { The ROK CDS is the Republic of Korea' Credit Default Swap } \\
\text { that can transfer Korea's sovereign risk exposure to others. }\end{array}$ \\
\hline & KRW FX & The KRW FX is KRW against US\$ FX rate. \\
\hline & Bid-Ask Spread & The bid-ask spread is market liquidity in the price dimension. \\
\hline \multirow{5}{*}{$\begin{array}{l}\text { International } \\
\text { Factors }\end{array}$} & $\begin{array}{l}\text { UST Yield } \\
\text { Curve Slope }\end{array}$ & $\begin{array}{l}\text { The UST yield curve slope is the rate difference between } \\
\text { long-term and short-term bonds, and an inverted yield curve } \\
\text { is often considered a bad sign for the economy. }\end{array}$ \\
\hline & US\$ TED & $\begin{array}{l}\text { The US\$ TED is the rate difference between the three-month } \\
\text { Treasury bill and the three-month US\$ LIBOR. The TED spread } \\
\text { is used as an indicator of credit risk. }\end{array}$ \\
\hline & VIX & $\begin{array}{l}\text { The CBOE variability index, VIX, is commonly referred to as } \\
\text { the fear index. }\end{array}$ \\
\hline & Policy Rate & $\begin{array}{l}\text { The policy rate is the rate determined by monetary authorities } \\
\text { such as the central bank. }\end{array}$ \\
\hline & MSCI World & $\begin{array}{l}\text { The MSCI World is a market cap weighted stock market index } \\
\text { of } 1,636 \text { stocks from companies throughout the world and is } \\
\text { intended to represent a broad cross-section of the } \\
\text { global markets. }\end{array}$ \\
\hline \multirow{5}{*}{$\begin{array}{l}\text { Risk } \\
\text { Factors }\end{array}$} & $\begin{array}{l}\text { Policy } \\
\text { Uncertainty }\end{array}$ & $\begin{array}{l}\text { Policy uncertainty is one of the risk factors for an economy } \\
\text { that can delay spending and investment decisions by } \\
\text { businesses and individuals. }\end{array}$ \\
\hline & $\begin{array}{l}\text { Geopolitical } \\
\text { Risk }\end{array}$ & $\begin{array}{l}\text { Geopolitical risks can affect or upset the domestic political and } \\
\text { social policies of other countries, including military conflicts, } \\
\text { civil wars, terrorist attacks, riots, sanctions, etc. }\end{array}$ \\
\hline & $\begin{array}{l}\text { Fiscal } \\
\text { Soundness } \\
\text { and Sovereign } \\
\text { Rating }\end{array}$ & $\begin{array}{l}\text { Fiscal soundness consists of debt, spending and tax revenues, } \\
\text { and worsening fiscal soundness could lead to a sovereign debt } \\
\text { crisis. The sovereign rating is an independent assessment of a } \\
\text { country's creditworthiness and an implicit prediction of } \\
\text { sovereign debt repayment ability and possible default. }\end{array}$ \\
\hline & $\begin{array}{l}\text { Regulations } \\
\text { and Taxes }\end{array}$ & $\begin{array}{l}\text { Regulations are rules created to control what the government } \\
\text { or other agencies do or what people do. Taxes are compulsory } \\
\text { financial charges of levy imposed upon taxpayers by } \\
\text { governmental organizations in order to fund various public } \\
\text { expenditures. }\end{array}$ \\
\hline & Property Rights & $\begin{array}{l}\text { Property rights are the legal rights that entities have on a } \\
\text { property and have four components: the right to use the good, } \\
\text { to earn an income from it, to transfer it to others, and the right } \\
\text { to enforce property rights. }\end{array}$ \\
\hline
\end{tabular}

\subsection{Respondent Selection and Survey}

To survey the factors that affect the investment decisions of global investors in an objective and reasonable manner, the survey participants were selected in consideration of the following criteria: 
- Working period: at least 15 years of investment experience

- Institution of employment: a variety in the types of institutions that the experts are employed at. At least one from each of the categories: investment banks, central bank, pension fund, insurances company, trust and asset management company, brokerage firm, government, and monetary authority.

- Location of the investment institution: a variety in the location of the institutions that the experts are employed at. At least, one from each of the categories: East Asian, South Asia, Europe, U.S., and Australia.

Based on this, a total of 28 experts were asked participate in the survey. The experts' institutions of employment consisted of the following: eight at investment banks, five at central banks, four at pension funds, four at insurance companies, three at trust and asset management companies, two at brokerages, one at the Korean government, and one at the monetary authority. As well, the location of the institutions are as follows: eight in East Asian countries, six at South East Asian countries, seven in European countries, five in the U.S., and two in Australia.

The survey was conducted from 27 June to 26 July 2019. In this study, pairwise comparison scales of 1 to 5 were used to give a clearer weight to each criterion, considering that many factors in the criteria have a close relationship with other factors due to the nature of the financial markets. A total of 28 questionnaires were distributed via e-mail or direct delivery, of which 26 received responses. The AHP method is a mathematical method for analyzing and organizing complex decisions using ratio scale measurement (De Felice et al. 2015). It has been applied in studies with small sample sizes to solicit and analyze hierarchical relationship, typically based on experts' opinion (Kil et al. 2016). Several studies reported findings using the AHP with small numbers of experts: five respondents (Peterson et al. 1995), five participants (Al-Harbi 2001), seven participants (Armacost et al. 1994), 18 participants (Mawapanga and Debertin 1996), 20 participants (Song et al. 2013), and 25 respondents (Huang and Yeh 2011).

The survey was conducted using the self-filling method by respondents. Out of the 26 responses, 20 final samples were selected. Two of the respondents were brokers who are not directly involved in investment decision and ultimately excluded from the sample in this study. In addition, three responses (two from pension funds and one from an insurance company) were excluded because individual CRs were higher than the level of threshold, $15 \%$ (CR of 3 the respondents was $39 \%, 20 \%$ and $16 \%$, respectively). Finally, to ensure that the number of short-term and long-term investors are equal, one of the investment bank responses representing the highest CR $(15 \%)$ was excluded. With regard to the CR allowance, Ho et al. (2005) recommended that CR be restricted to $10 \%$ or $15 \%$ for individual experts, and for group responses, the CR could be mitigated to $20 \%$ to allow for non-experts responses. Objectively, this survey sample is considered sufficiently valid for the following reasons: (1) The 20 samples used in this study showed a CR of less than $15 \%$ for individual respondents and less than $2 \%$ for group respondents. This is based on an analysis using the AHP system provided by Goepel (2013). (2) As presented in Table 4, the groups of experts who responded are well distributed by their institution of employment and the regions of their location, with every group having a frequency of $30 \%$ or less. (3) Respondents are experts with an average of 25 years of experience in investing.

Table 4. Distribution of survey respondents by classification.

\begin{tabular}{|c|c|c|c|c|c|c|c|c|}
\hline Investment Institution & Frequency & $\%$ & Region & Frequency & $\%$ & Working Period & Frequency & $\%$ \\
\hline Investment Bank & 6 & 30 & East Asia & 5 & 25 & 10-19 years & 3 & 15 \\
\hline Asset Management and Trust & 3 & 15 & South Asia & 5 & 25 & 20-29 years & 5 & 25 \\
\hline Central Bank & 4 & 20 & Australia & 2 & 10 & Over 30 years & 12 & 60 \\
\hline Pension Fund & 2 & 10 & Europe & 5 & 25 & - & - & - \\
\hline Insurance Company & 3 & 15 & U.S. & 3 & 15 & - & - & - \\
\hline Monetary Authority and Gov't & 2 & 10 & - & - & - & - & - & - \\
\hline Total & 20 & 100 & Total & 20 & 100 & Total & 20 & 100 \\
\hline
\end{tabular}




\section{Empirical Results}

\subsection{Weights of the Factors and Attributes}

Local priorities that represent the relative effects of a set of parts can be created using a pair of comparison matrices (Chen 2006). A local priority is the calculation of primary weights using the AHP's pairwise comparison, which determines the degree of weights for each variable in a percentage format that sum to $100 \%$ (Albayrak and Erensal 2004).

\subsubsection{Local Weights for Level 2}

As shown in Figure 3, international factors (38.1\%) were considered to be most important in the analysis of factors that affect global investors' KTB investments, followed by domestic factors (37\%) and risk factors $(24.9 \%)$. This means that investors placed relatively more importance on direct returns on investments and hedge costs over risk factors in general.
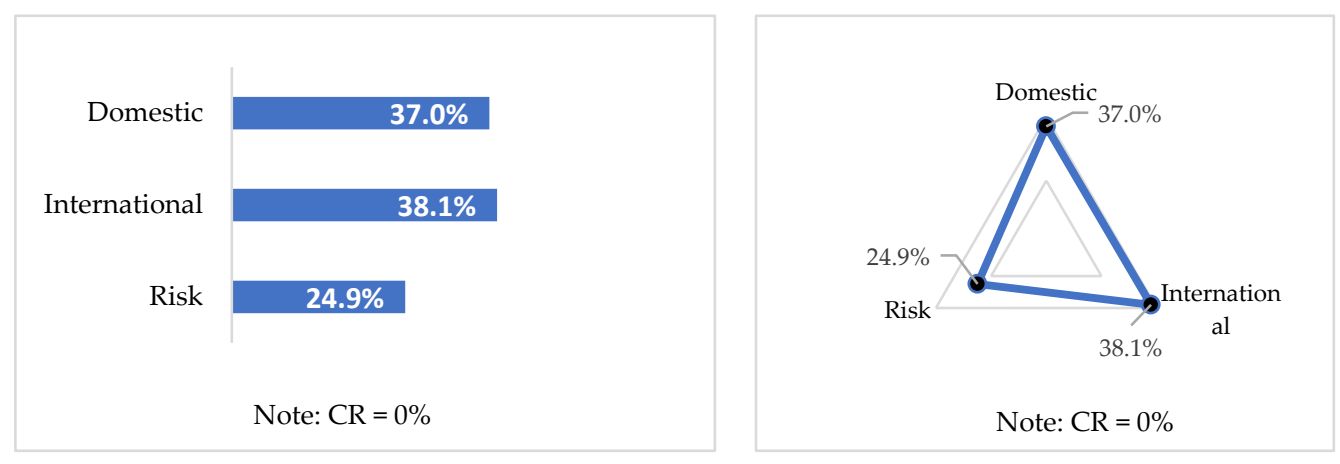

Figure 3. Local weights for level 2.

\subsubsection{Local Weights for Level 3}

\section{Local Weights for Domestic Factors}

Domestic factors were classified into five sub-criteria: KTB yield (benchmark return on the Korean LCY bond market), KTB TED (benchmark for market arbitrage transactions), ROK CDS (benchmark for Korean sovereign default risk), KRW FX (KRW vs. US\$ exchange rate) and bid-ask spread (market liquidity).

As shown in Figure 4, global investors' decision to invest in KTBs is shown to be influenced by the above variables in the following order of importance: KTB returns $(29.8 \%)$, Korea CDS $(23.9 \%)$, KTB TED (20.5\%), KRW FX (15.1\%), and bid-ask spread (10.7\%).
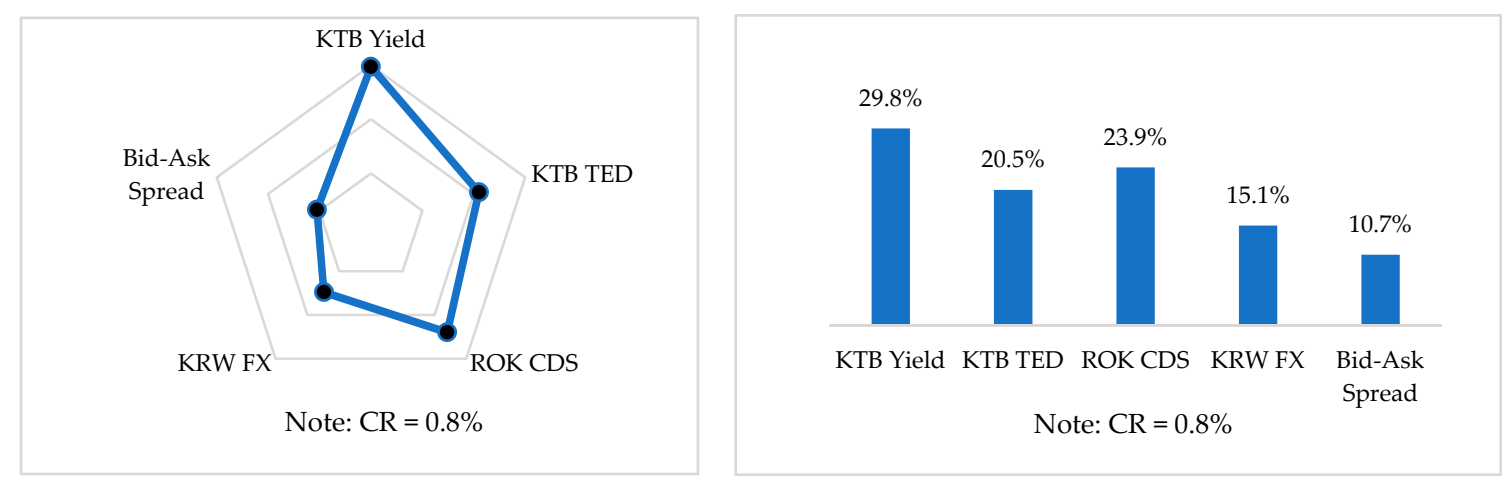

Figure 4. Local weights for domestic factors.

2. Local Weights for International Factors 
International factors are classified as U.S. Treasury yield curve slope (sign of global economic situation), US\$ TED (indicator for US\$ loans in inter-bank), policy rates (interest rate by U.S. Federal reserve and Bank of Korea), VIX (indicator for market volatility, fear gauge), and MSCI World (benchmark for global stock funds).

As presented in Figure 5, the policy rate (31.3\%) has the most impact on global investors' decision to invest in KTBs, followed by the U.S. Treasury yield curve slope (21.9\%), US\$ TED spread (20.3\%), VIX (14.6\%), and MSCI World (11.8\%).

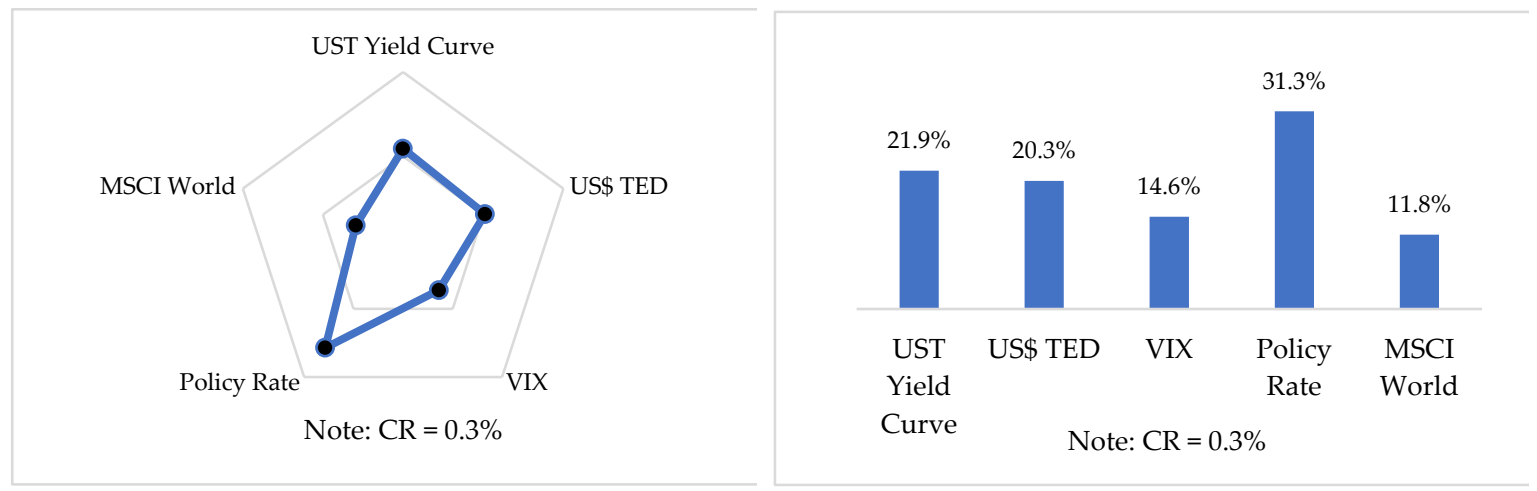

Figure 5. Local weights for international factors.

3. Local Weights for Risk Factors

Risk factors are classified as policy uncertainty, geopolitical risk, fiscal soundness and sovereign credit rating, regulations and taxes, and property rights.

As shown in Figure 6, fiscal soundness and sovereign credit rating $(24.2 \%)$, policy uncertainty $(23.8 \%)$, geopolitical risk $(22.7 \%)$ have larger impacts, while regulation and taxation $(19.8 \%)$, and property rights $(9.4 \%)$ have smaller impacts in global investors' decision to invest in KTBs.

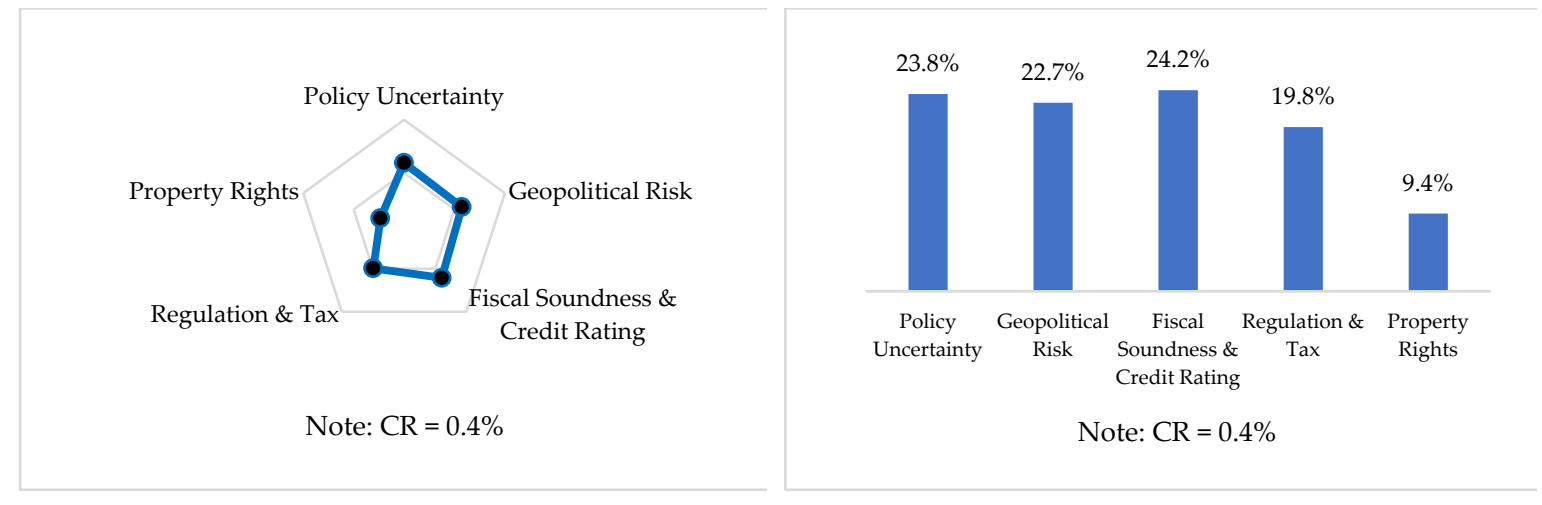

Figure 6. Local weights for risk factors.

\subsubsection{Global Weights for Level 3}

The global weight is a multiplication of the importance derived by each criterion. The sum of the least significant analyses of the importance of each lower layer in a single criterion equals $100 \%$. If the local weights represent the relative rankings of the pairwise comparison at each level, the global weight is useful in determining the degree of integrated importance of the minimum unit factors for the purpose of the AHP.

As shown in Figure 7, policy rates, the KTB yield, and the ROK CDS had the greatest impacts on global investors' investment in KTBs, while property rights, the bid-ask spread, and MSCI World were found to be the least influential. 


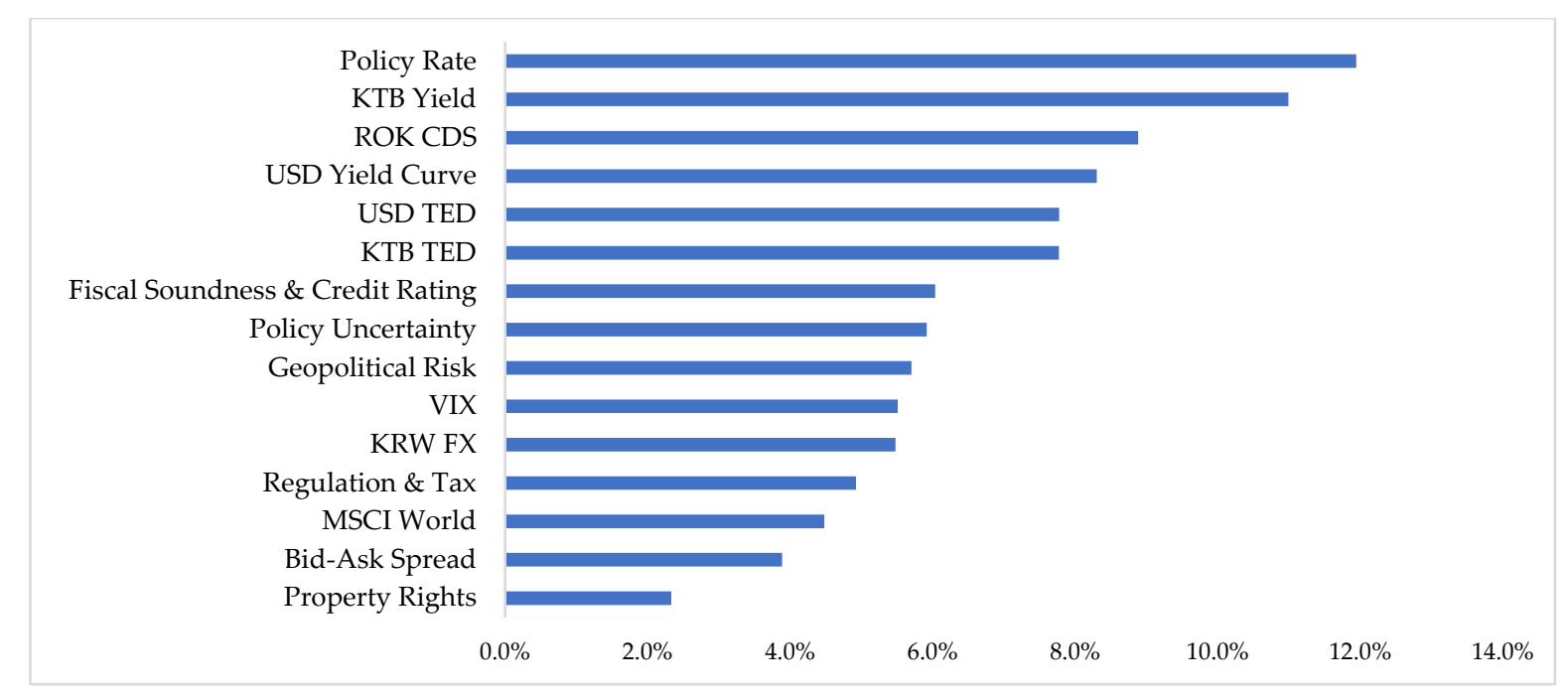

Figure 7. Global weights.

The results show that the share of KTB TED, which had been the absolute weight of KTB investments by global investors until the beginning of 2010, has recently decreased and spread for various purposes. This result is different from previous studies, which concluded that global investments in KTBs are most impacted by the KTB TED spread. Up until the early 2010s, global investors' investments in KTBs were concentrated in investments related to arbitrage transaction opportunities, but the proportion of arbitrage transactions have gradually decreased. Recently, global investors are investing in KTBs for more varied purposes, and therefore more diverse factors are influencing global investors' KTB investment decisions. Also, the importance of the impact of US\$ TED, which has been one of the important factors in the past, has decreased. This translates into a decrease in the proportion of investment banks and private funds that require US\$ financing in the short-term money market.

\subsection{Weights of the Factors and Attributes Divided by Two Groups}

To draw more sophisticated implications, we divide the respondents of the survey into two groups and compare their weights. We classified investors with short-term investment tendencies, such as investment banks and asset management companies, into group 1, and investors with long-term tendency, such as foreign central banks, pension funds and insurance companies, into group 2 . Each group contained nine samples.

The purpose of this comparative analysis is to consider recent trend in the LCY government bond market. In addition, analyzing each investor's propensity is important in determining ideal policy objectives.

\subsubsection{Local Weights for Level 2 between Group 1 and Group 2}

As shown in Figure 8, it has been found that group 1 investors recognized importance in the order of domestic, international, and risk factors, and group 2 investors in the order of international, risk and domestic factors. In other words, both long-term and short-term investors were strongly influenced by international factors, and long-term investors perceive risk factors to be more important than domestic market factors. 


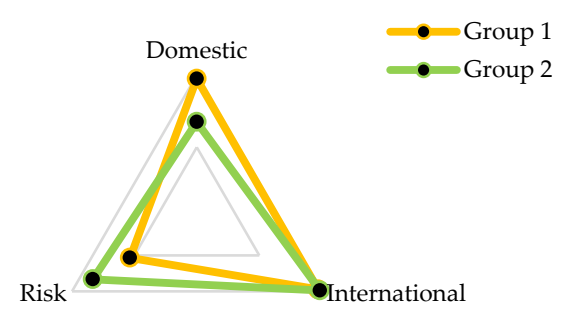

Note: $\mathrm{CR}$ in Group $1=0.5 \%$. CR in Group $2=1.2 \%$

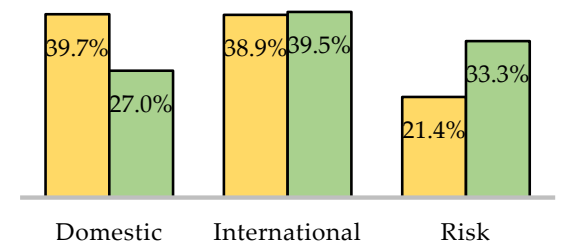

$\square$ Group $1 \quad \square$ Group 2

Note: $\mathrm{CR}$ in Group $1=0.5 \%$, CR in Group $2=1.2 \%$

Figure 8. Local weights for level 2 between group 1 and group 2.

\subsubsection{Local Weights for Level 3 between Group 1 and Group 2}

\section{Local Weights for Domestic Factors}

As shown in Figure 9, it has been found that group 1 investors recognized the KTB TED spread to be most important criteria, followed by KTB yield, ROK CDS, KRW FX and bid-ask spread. On the other hand, group 2 investors recognized the KTB yield to be most important factor, followed by ROK CDS, KRW FX, bid-ask spread, and KTB TED. In addition, group 2 investors were not significantly affected by the KTB TED spread, a measure of arbitrage transactions, and more sensitive to ROK CDS, a measure of sovereign default risk.
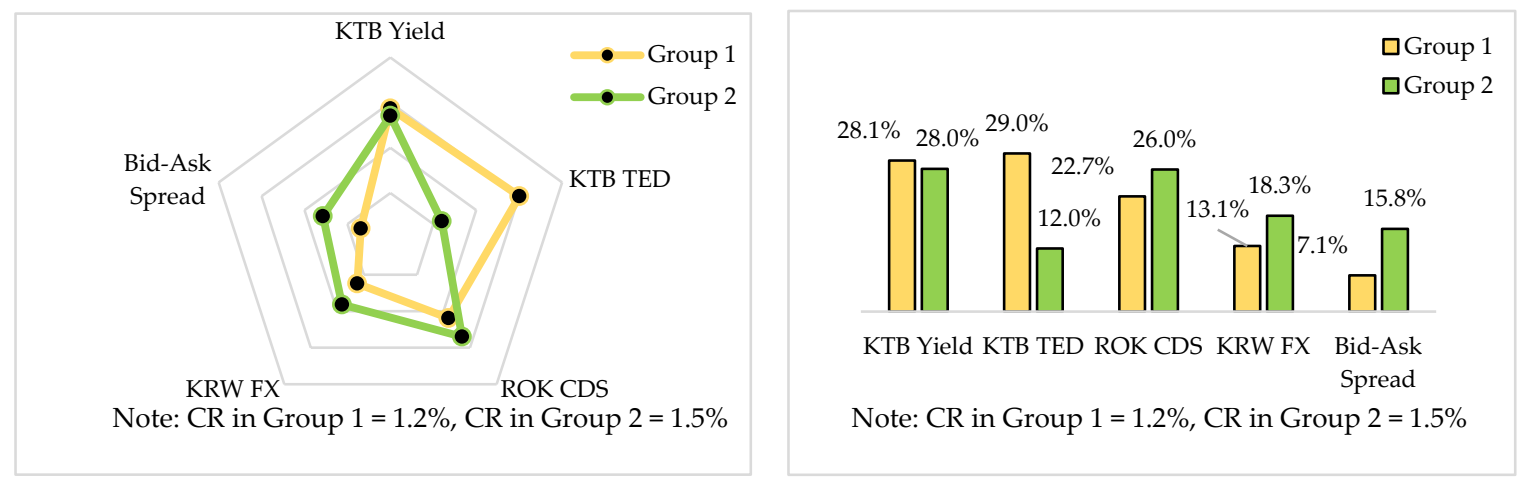

Figure 9. Local weights for domestic factors between group 1 and group 2.

\section{Local Weights for International Factors}

As shown in Figure 10, investors included in group 1 recognized monetary authority's policy rate to be the most important variable, followed by US\$ TED, U.S. Treasury yield curve slope, VIX, and MSCI World. On the other hand, investors in group 2 responded that they considered US\$ TED to be much less important. This shows that group 1 is more sensitive to US\$ TED spread because of the need for US\$ financing in the short-term financial market, while group 2, which does not require direct US\$ funding, is more sensitive to market volatility and stock price volatility. 


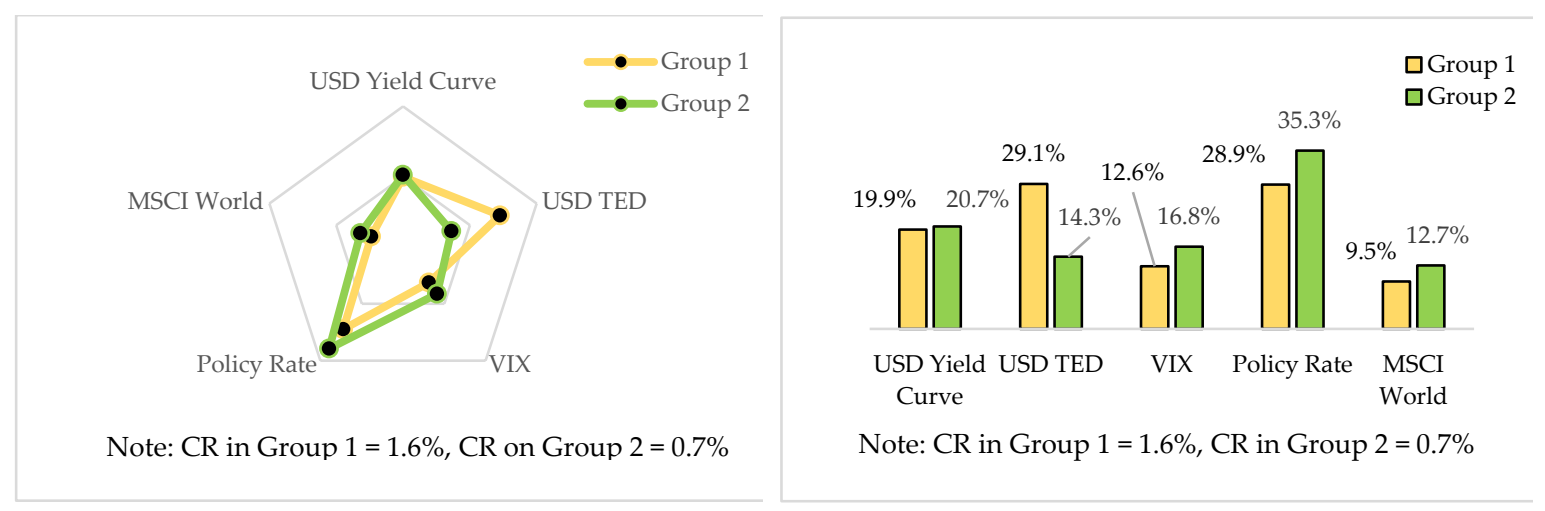

Figure 10. Local weights for international factors between group 1 and group 2.

\section{Local Weights for Risk Factors}

As shown in Figure 11, group 1's decision to invest in KTBs are most affected by policy uncertainty, followed by regulations and taxes, financial health and credit ratings, geopolitical risks and property rights. On the other hand, group 2's investment decisions are found to be affected most strongly by fiscal soundness and credit rating, followed by policy uncertainty, regulation and tax, and property rights. It is noteworthy that long-term investors take geopolitical risk more seriously than short-term investors.

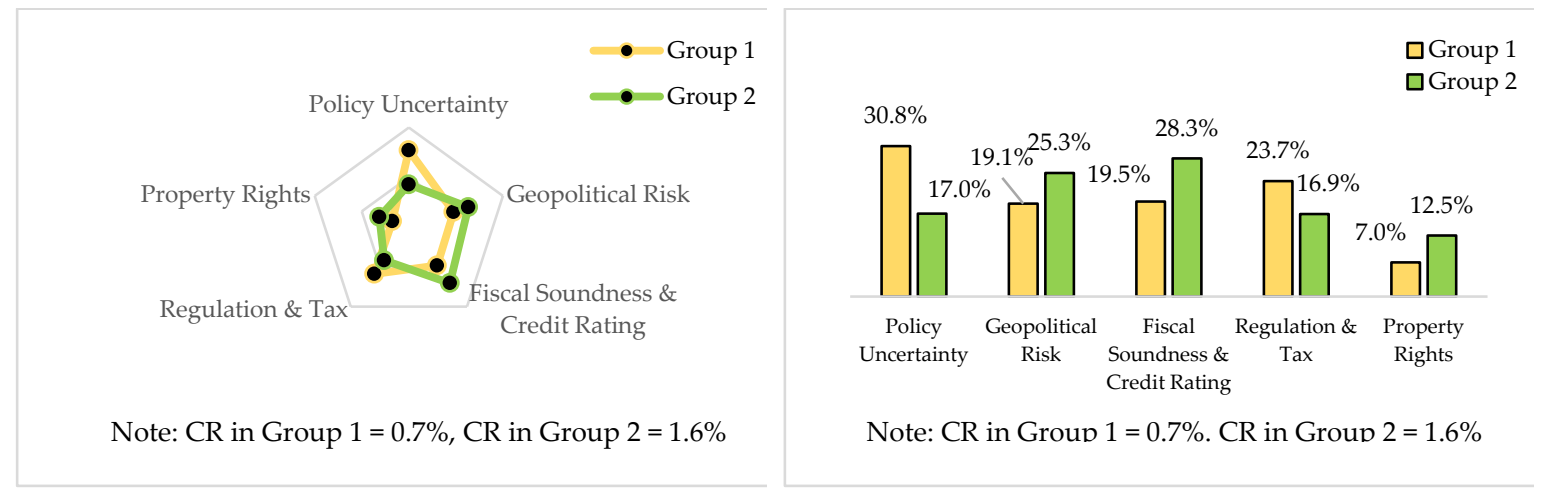

Figure 11. Local weights for risk factors between group 1 and group 2.

\subsubsection{Global Weights for level 3 in Two Groups}

As shown in Figure 12, for group 1 investors, who have a propensity for short-term investments, it appears that they are most affected by the KTB TED spread, KTB yield, US\$ TED, and the policy rate. On the other hand, group 2 investors, who prefer long-term investment, appear to be more sensitive to the country's financial situation, geopolitical risks around the Korean peninsula, the possibility of a global economic recession, as well as the policy interest rates of monetary authorities. 


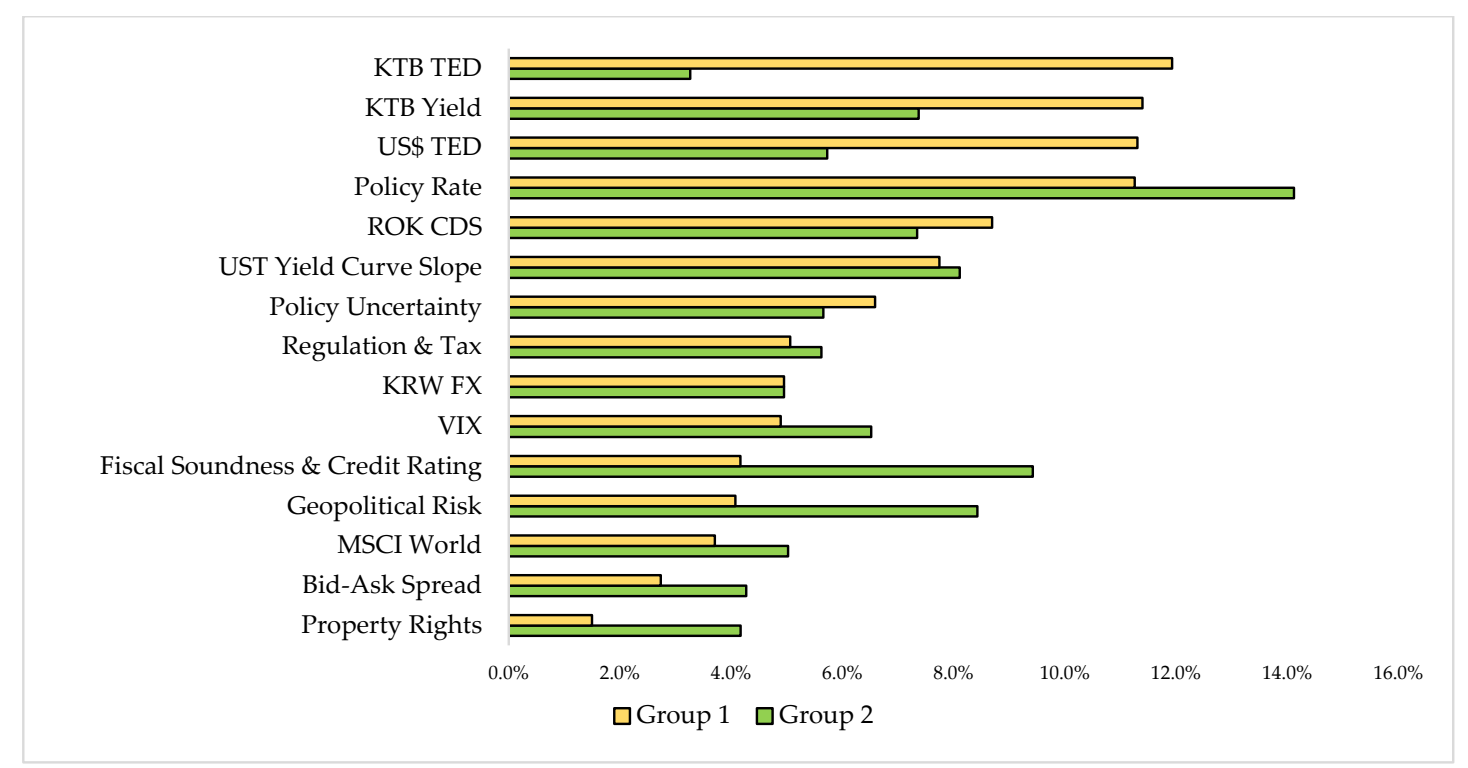

Figure 12. Global weights between group 1 and group 2 .

\subsection{Consensus Level}

Consensus should be strictly distinguished from consistency. Goepel (2013) proposed to have consensus estimates of the AHP group consensus indicators, i.e., priorities among participants, to quantify the group's consensus. The range of these indicators is $0 \%$ to $100 \%$. Zero percent corresponds to no consensus at all, and $100 \%$ to full consensus. This is a measure of priority homogeneity among participants and can also be interpreted as a measure of redundancy among group members (Jost 2006). Values of less than $50 \%$ indicate that there is virtually no agreement within the group and that the judgements are highly variable. Values in the range of $80 \%$ to $90 \%$ represent a prioritized overlay of group members and an outstanding judgment consensus.

As shown in Figure 13, consensus in most cases is $50 \%$ to $80 \%$, which is a moderate level (the values of consensus, lambda, and CR are given in Table S1 in the Supplementary Materials). The consensus in the risk factors of group 1 and the domestic factors of group 2 exceeded $85 \%$, indicating a high consensus. In addition, there is a relatively high consensus among the risk criteria, as well as level 2 criteria.

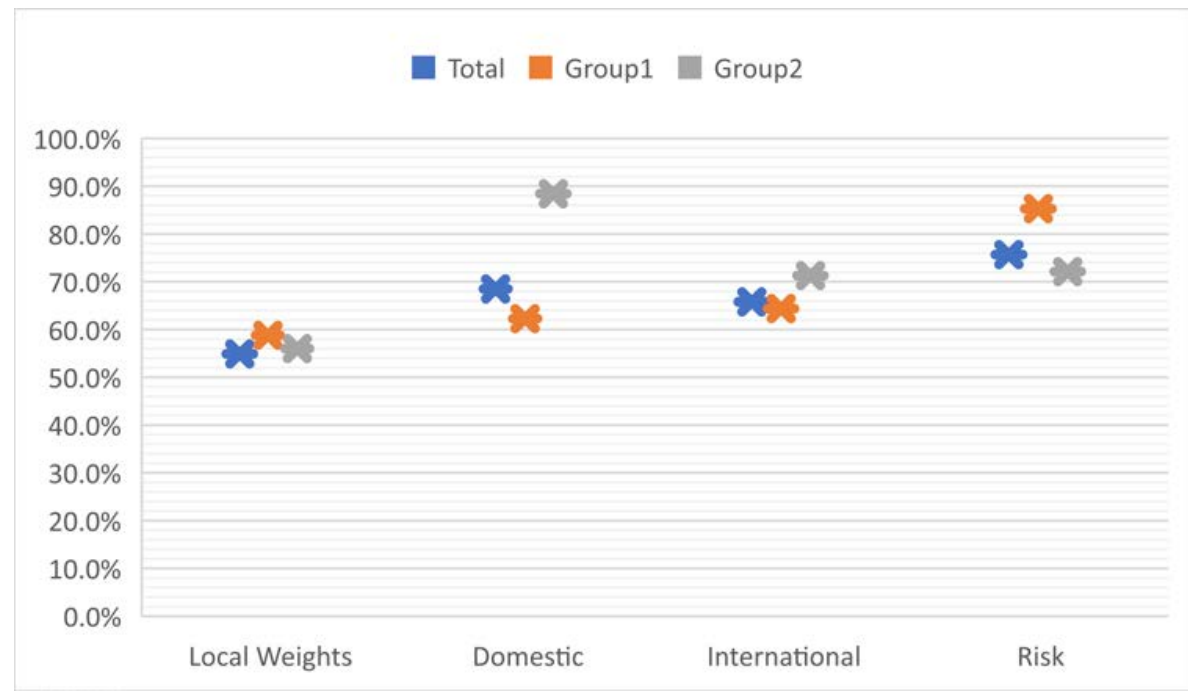

Figure 13. Consensus measure. 


\section{Conclusions}

This study uses the AHP analysis technique to analyze the importance of decision factors that affect global portfolio investors' decision to invest in KTBs.

The hierarchical structure of AHP analysis consists of three criteria, domestic, international and risk factors, and five sub-criteria for each criterion. The domestic criterion has the following proxies as sub-criteria: KTB yields, KTB TED, ROK CDS, KRW FX, and the bid-ask spread. The international criterion consists of five sub-criteria: the U.S. Treasury yield curve slope, US\$ TED, the policy rate, VIX, and MSCI World. Finally, the risk criterion has the following sub-criteria: policy uncertainty, geopolitical risks, fiscal soundness and sovereign credit ratings, regulations and taxes, and property rights. A large number of possible decision factors were found through detailed research of the existing literature. Based on this, the 15-factor criteria and the hierarchical relationship between them were determined after conducting several rounds of interviews and brainstorming sessions with experts. In addition, a survey was distributed to a panel of experts who were selected by considering the length of their professional experience institution of employment, and the institutions' locations. Based on the survey responses, the importance of local and global weightings were analyzed. To create more sophisticated analysis, we grouped the survey responses by the respondents' investment tendencies (short or long-term) and performed further analysis. This analysis is meaningful in that it provides new implications regarding recent changes in global investors' investment goals and strategies in investing in KTBs. Before the early 2010s, investments by global investors with short-term investment propensities were the absolute majority of KTB investment. However, the proportion of long-term investors has been increasing, and exceeded 50 percent as of the end of 2018 (Ministry of Economy and Finance 2019).

The main implications of this study are that global investors' decision to invest in Korean LCY bonds is not only influenced by monetary authorities' policy rate decisions and bond yields, but also by sovereign default risks, the possibility of a global recession, short-term US\$ funding conditions, and the ROK's financial stability. Based on the analysis by the investor s' tendencies, investors with short-term investment tendencies, such as investment banks and asset management firms, are more sensitive to international and domestic factors and less affected by risk factors. In particular, many short-term investors are still found to be investing in KTBs for the purpose of arbitrage trading and proprietary trading, and therefore greatly influenced by US\$ financing conditions. On the other hand, investors with long-term investment tendencies such as foreign central banks, pension funds and insurance companies, are found to be more sensitive to international and risk factors and less sensitive to domestic factors. In particular, global policy interest rate decisions, fiscal soundness and sovereign rating, the possibility of a global economic downturn, and geographical risks are found to be considered important by long-term investors. It is essential to increase the proportion of investors with long-term investment tendencies in order to stabilize the financial markets and to ensure sustainable government funding (Group of Thirty 2013). To do this, active management of risk factors is necessary. In particular, the ROK's government needs to improve the consistency of policies and taxation, ease market regulations, develop the secondary markets, and improve property rights.

This study was conducted with a focus on the KTB markets. Therefore, there is a limit to whether these findings can be applied to investments in LCY bond markets in other emerging and developed countries. In future research, it may be interesting to expand the scope of research to analyze and compare the decision factors in other emerging markets, and gain market insight through the propensity survey of both global and local investors. In addition, increasing the sample size and further diversifying sample groups will result in more meaningful analysis.

Supplementary Materials: The following are available online at http://www.mdpi.com/2227-9091/7/4/101/s1, Table S1: The value of consensus, Lambda, and CR.

Author Contributions: Conceptualization, J.Y.J.; methodology, J.Y.J.; software, J.Y.J.; validation, J.Y.J.; formal analysis, J.Y.J.; investigation, J.Y.J.; resources, J.Y.J.; data curation, J.Y.J.; writing一 original draft preparation, J.Y.J.; writing-review and editing, M.J.P.; visualization, J.Y.J.; supervision, M.J.P.; project administration, J.Y.J.; funding acquisition, J.Y.J. 
Funding: This research received no external funding.

Acknowledgments: We appreciate the valuable advice of Erdal Atukeren of BSL and the proofreading and assistance of Brian Jang of Marcus \& Associates. We would also like to thank experts who participated in in-depth interviews and brainstorming sessions, provided feedback on the research structure, as well as survey respondents who responded to the survey. We are thankful to anonymous referees whose comments and suggestions on earlier versions of the paper led to many improvements.

Conflicts of Interest: The authors declare no conflict of interest.

\section{References}

Ahn, Hee-Joon, Seung-Pyo Jeon, and Jong-Bum Chay. 2010. The Effects of the News Related to the North-South Korean Relationship on the Korean Stock Markets. Journal of Korean Economic Analysis 16: 199-238.

Aizenman, Joshua, and JaeWoo Lee. 2007. International Reserves: Precautionary versus Mercantilist Views, Theory and Evidence. Open Economies Review 18: 191-214. [CrossRef]

Albayrak, Esra, and Yasemin Claire Erensal. 2004. Using Analytic Hierarchy Process (AHP) to Improve Human Performance: An Application of Multiple Criteria Decision-Making Problem. Journal of Intelligent Manufacturing 15: 491-503. [CrossRef]

Al-Harbi, Kamal M. Al-Subhi. 2001. Application of the AHP in project management. International Journal of Project Management 19: 19-27. [CrossRef]

Ang, Andrew, and Monika Piazzesi. 2003. No-Arbitrage Vector Autoregression of Term Structure Dynamics with Macroeconomic and Latent Variables. Journal of Monetary Economics 50: 745-87. [CrossRef]

Antonakakis, Nikolaos, Ioannis Chatziantoniou, and George Filisb. 2013. Dynamic Co-Movements of Stock Market Returns, Implied Volatility and Policy Uncertainty. Economics Letters 120: 87-92. [CrossRef]

Armacost, Robert L., Paul J. Componation, Michael A. Mullens, and William W. Swart. 1994. An AHP Framework for Prioritizing Customer Requirements in QFD: An Industrialized Housing Application. IIE Transactions 26: 72-79. [CrossRef]

Asian Development Bank. 2018. Asian Bond Monitor, November 2018. Available online: https://www.adb.org/ sites/default/files/publication/467066/abm-nov-2018.pdf (accessed on 15 May 2019).

Asian Development Bank. 2019. Asian Bond Monitor, March 2019. Available online: https://www.adb.org/sites/ default/files/publication/491531/abm-mar-2019.pdf (accessed on 17 June 2019).

Baele, Lieven, Geert Bekaert, and Koen Inghelbrecht. 2010. The Determinants of Stock and Bond Return Comovements. The Review of Financial Studies 23: 2374-28. [CrossRef]

Bahmani, Nick, David Yamoah PotkinBasseer, and Farahmand Rezvani. 1987. Using the Analytic Hierarchy Process to Select Investment in a Heterogenous Environment. Mathematical Modelling 8: 157-16. [CrossRef]

Basu, Susanto, and Brent Bundick. 2017. Uncertainty Shocks in a Model of Effective Demand. The Journal of The Econometrica Society 85: 937-58. [CrossRef]

Bekaert, Geert, Robert J. Hodrick, and Xiaoyan Zhang. 2009. International Stock Return Comovements. The Journal of Finance 64: 2591-2626. [CrossRef]

Bernanke, Ben, and Alan S. Blinder. 1992. The Federal Funds Rate and the Transmission of Monetary Policy. American Economic Review 82: 901-21.

Bilson, Christopher M., Timothy J. Brailsford, and Vincent C. Hooper. 2002. The Explanatory Power of Political Risk in Emerging Markets. International Review of Financial Analysis 11: 1-27. [CrossRef]

Bjornland, Hilde C., and Kai Lietemo. 2009. Identifying the Interdependence between US Monetary Policy and the Stock Market. Journal of Monetary Economics 56: 275-82. [CrossRef]

Bloom, Nicholas. 2014. Fluctuations in Uncertainty. Journal of Economic Perspectives 28: 153-76. [CrossRef]

Bordo, Michael D. 2008. An Historical Perspective on the Crisis of 2007-2008 No. 14569. NBER Working Paper 14569: 1-23.

Burger, John D., and Francis E. Warnock. 2007. Foreign Participation in Local Currency Bond Markets. Review of Financial Economics 16: 291-304. [CrossRef]

Campbell, John Y. Campbell, Yeung Lewis Chanb, and Luis M. Viceira. 2013. Handbook of the Fundamentals of Financial Decision Making. World Scientific Handbook in Financial Economics Series; Singapore: World Scientific, pp. 809-48. 
Chen, Ching-Fu. 2006. Applying the Analytical Hierarchy Process (AHP) Approach to Convention Site Selection. Journal of Travel Research 45: 167-74. [CrossRef]

Cheung, Michael Tow, and Ziqi Liao. 2009. Investing in Real-World Equity Markets with an AHP-based Decision Framework. Journal of Decision Systems 18: 149-63. [CrossRef]

Christensen, Jens H. E., Eric Fischer, and Patrick Shultz. 2019. Bond Flows and Liquidity: Do Foreigners Matter? Working Paper 2019-08. San Francisco: Federal Reserve Bank of San Francisco, pp. 1-31.

Christiano, Lawrence J., and Martin Eichenbaum. 1992. Liquidity Effects and the Monetary Transmission Mechanism. American Economic Review 82: 346-53.

Christiano, Lawrence J., Martin Eichenbaum, and Charles L. Evans. 1996. The Effects of Monetary Policy Shocks: Evidence from the Flow of Funds. Review of Economics and Statistics 78: 16-34. [CrossRef]

Connolly, Robert, Chris Stivers, and Licheng Sun. 2005. Stock Market Uncertainty and the Stock-Bond Return Relation. Journal of Financial and Quantitative Analysis 40: 161-94. [CrossRef]

De Felice, Fabio, Antonella Petrillo, and Claudio Autorino. 2015. Development of a framework for sustainable outsourcing: Analytic Balanced Scorecard Method (A-BSC). Sustainability 7: 8399-8419. [CrossRef]

Diebolda, Francis X., Glenn D. Rudebusch, and S. Boragăn Aruoba. 2006. The Macroeconomy and the Yield Curve: A dynamic Latent Factor Approach. Journal of Econometrics 131: 309-38. [CrossRef]

Du, Wenxin, Alexander Tepper, and Adrien Verdelhan. 2018. Deviations from Covered Interest Rate Parity. The Journal of Finance 73: 915-57. [CrossRef]

Duffie, Darrell. 1998. Defaultable Term Structure Models with Fractional Recovery of Par. Stanford: Graduate School of Business, Stanford University.

Estrella, Arturo, and Frederic S. Mishkin. 1995. The Term Structure of Interest Rates and Its Role in Monetary Policy for The European Central Bank. European Economic Review 41: 1375-401. [CrossRef]

Goepel, Klaus D. 2013. Implementing the Analytic Hierarchy Process as a Standard Method for Multi-Criteria Decision Making in Corporate Enterprises-A New AHP Excel Template with Multiple Inputs. Paper presented at International Symposium on the Analytic Hierarchy Process, Kuala Lumpur, Malaysia, June 23-26; pp. 1-10.

Gordon, David B., and Eric M. Leeper. 1994. The Dynamic Impacts of Monetary Policy: An Exercise in Tentative Identification. Journal of Political Economy 102: 1228-47. [CrossRef]

Group of Thirty. 2013. Long-Term Finance and Economic Growth. Washington: Working Group on Long-Term Finance.

Gyntelberg, Jacob, Mico Loretan, Tientip Subhanij, and Eric Chan. 2014. Exchange Rate Fluctuations and International Portfolio Rebalancing. Emerging Markets Review 18: 34-44. [CrossRef]

Hamilton, James D. 2003. What is an Oil Shock? Journal of Econometrics 13: 363-98. [CrossRef]

Herbst, Anthony F., and Craig W. Slinkman. 1984. Political-Economic Cycles in the U.S. Stock Market. Financial Analysts Journal 40: 38-44. [CrossRef]

Ho, Daniel, Graeme Newell, and Anthony Walker. 2005. The Importance of Property-specific Attributes in Assessing CBD Office Building Quality. Journal of Property Investment and Finance 23: 424-44. [CrossRef]

Hong, Chung Hyo. 2011. An Empirical Study on Price Discovery among CDS Spread, Won/Dollar Spot and Futures Markets. Korean Journal of Financial Engineering 10: 103-21. [CrossRef]

Houweling, Patrick, and Ton Vorst. 2005. Pricing Default Swaps: Empirical Evidence. Journal of International Money and Finance 24: 1200-25. [CrossRef]

Huang, Rong-Yau, and Cheng-Hung Yeh. 2011. Development of an Assessment Framework for Green Highway Construction. Journal of the Chinese Institute of Engineers 31: 573-85. [CrossRef]

Hull, John, Mirela Predescu, and Alan White. 2004. The Relationship between Credit Default Swap Spreads, Bond Yields, and Credit Rating Announcements. Journal of Banking \& Finance 28: 2789-811.

Jang, Jae Young, and Erdal Atukeren. 2019. Sustainable Local Currency Debt: An Analysis of Foreigners' Korea Treasury Bonds Investments Using a LA-VARX Model. Sustainability 11: 3603. [CrossRef]

Jost, Lou. 2006. Entropy and Diversity. OIKOS 113: 363-75. [CrossRef]

Kawaller, Ira G. 1997. The TED Spread. Derivatives Quarterly 3: 46-59.

Kil, Sung-Ho, Dong Kun Lee, Jun-Hyun Kim, Ming-Han Li, and Galen Newman. 2016. Utilizing the Analytic Hierarchy Process to Establish Weighted Values for Evaluating the Stability of Slope Revegetation based on Hydroseeding Applications in South Korea. Sustainability 8: 58. [CrossRef] 
Kim, Chi-Wook. 2011. Inter-Korean Relations and Korea Discount: An Analysis of Foreign Investors Stock Trading. Journal of Peace and Unification Studies 3: 219-52.

Kim, Do Yeon. 2012. Effects of Foreign Exchange Risk on International Portfolio Investment in Northeast Asian Countries and Korea. The Journal of Northeast Asian Economic Studies 24: 1-31.

Kim, Dong Soon, and Yu Jin Jung. 2015. The Effect of the Global Financial and Eurozone Debt Crises on European and Emerging Market Countries' Sovereign Bond Markets and Foreign Investment in the Korean Government Bonds. Korean Academy of International Business 26: 1-27.

Kim, Hong Bae, Myoung Jong Kim, and Sung Jae Rowe. 2013. Price Discovery and Volatility Transmission between Korean Sovereign CDS and ROK Bond Markets. The Korean Journal of Financial Engineering 12: 51-74.

Kontonikas, Alexandros, and Zivile Zekaite. 2018. Monetary Policy and Stock Valuation: Structural VAR Identification and Size Effects. Quantitative Finance 18: 837-48. [CrossRef]

Lavigne, Robert, Subrata Sarker, and Garima Vasishtha. 2014. Spillover Effects of Quantitative Easing on Emerging-Market Economies. Bank of Canada Review (Autumn) 2014: 23-32.

Le, Quan Vu, and Paul J. Zak. 2006. Political Risk and Capital Flight. Journal of International Money and Finance 25: 308-29. [CrossRef]

Lee, KeunYeoung. 2002. The Correlation Analysis of Volatility on Stock, Bond and Money Market. Kukje Kyungje Yongu 8: 191-212.

Leeper, Eric M., and David B. Gordon. 1992. In Search of the Liquidity Effect. Journal of Monetary Economics 29: 341-69. [CrossRef]

Liao, Ziqi, and Michael Tow Cheung. 2012. A Multi-dimensional Decision Framework to Support Corporate Bond Investment. Journal of Decision System 21: 161-70. [CrossRef]

Mahmood, Wan Mansor, and Nazihah Mohd Dinniah. 2009. Stock Returns and Macroeconomics Variables: Evidence from the Six Asian-Pacific Countries. International Research Journal of Finance and Economics 30: 154-64.

Mawapanga, Mwana N., and David L. Debertin. 1996. Choosing between Alternative Farming Systems: An Application of the Analytic Hierarchy Process. Review of Agricultural Economies 18: 385-401. [CrossRef]

MacRae, C. Duncan. 1977. A Political Model of the Business Cycle. Journal of Political Economy 85: $239-64$. [CrossRef]

Ministry of Economy and Finance. 2019. 2018 Korea Treasury Bonds. Available online: http://ktb.moef.go.kr/eng/ main.do (accessed on 2 June 2019).

Miron, Paul, and Philip Swannell. 1991. Pricing and Hedging Swaps. London: Euromoney Publications PLC.

Mun, Kyun Chun. 2007. Volatility and Correlation in International Stock Markets and the Role of Exchange Rate Fluctuations. Journal of International Financial Markets, Institutions and Money 17: 25-41. [CrossRef]

Nordhaus, William D. 1975. The Political Business Cycle. Review of Economic Studies 42: 169-90. [CrossRef]

Park, Jae Hwan, and Chun Kyu Kim. 2013. The Effect of Policy Rate Adjustments in US on the Korean Bond. The Journal of the Korea Contents Association 13: 344-54. [CrossRef]

Pastor, Lubos, and Pietro Veronesi. 2012. Uncertainty about Government Policy and Stock Prices. The Journal of Finance 67: 1219-64. [CrossRef]

Peiris, Shanaka J. 2010. Foreign Participation in Emerging Markets' Local Currency Bond Markets. IMF Working Paper, WP/10/88. Washington: International Monetary Fund, pp. 1-19.

Peterson, David L., David G. Silsbee, and Daniel L. Schmoldt. 1995. A Case Study of Resources Management Planning with Multiple Objectives and Projects. Environmental Management 18: 729-42. [CrossRef]

Popper, Helen. 1993. Long-term Covered Interest Parity: Evidence from Currency Swaps. Journal of International Money and Finance 12: 439-48. [CrossRef]

Saaty, Thomas L., Paul C. Rogers, and Ricardo Pell. 1980. Portfolio Selection through Hierarchies. Journal of Portfolio Management 6: 16-21. [CrossRef]

Shapiro, A. C. 2006. Multinational Financial Management, 5th ed. Hoboken: John Wiley \& Sons.

Song, Jae Ho, Yoon Seob Nam, and Hwa Soon Lim. 2013. A study for JeJu-Tourism Policy Importance with use AHP. TamLa MunHwa 43: 321-42.

Steiguer, Joseph E., Jennifer Duberstein, and Vicente Lopes. 2003. The Analytic Hierarchy Process as a Means for Integrated Watershed Management. Paper presented at Conference on Research on the Watersheds, Benson, AZ, USA, October 27-30; pp. 736-40. 
Strongin, Steven. 1995. The Identification of Monetary Policy Disturbances Explaining the Liquidity Puzzle. Journal of Monetary Economics 35: 463-97. [CrossRef]

Takezawa, Nobuya. 1995. Currency Swaps and Long-term Covered Interest Parity. Economics Letters 49: 181-85. [CrossRef]

Triantaphyllou, Evangelos. 2000. Multi-criteria Decision-Making Methods. A Comparative Study. Applied Optimization Book Series 44: 5-21.

Wright, Jonathan H., and Hao Zhou. 2009. Bond Risk Premia and Realized Jump Risk. Journal of Banking E Finance 33: 2333-45.

Zhang, Yue-Jun, and Yi-Ming Wei. 2010. The Crude Oil Market and the Gold Market: Evidence for Cointegration, Causality and Price Discovery. Resources Policy 35: 168-77. [CrossRef]

C 2019 by the authors. Licensee MDPI, Basel, Switzerland. This article is an open access article distributed under the terms and conditions of the Creative Commons Attribution (CC BY) license (http://creativecommons.org/licenses/by/4.0/). 